\title{
Pengembangan Sugeno Fuzzy Model Untuk Pengaturan Kecepatan Motor Induksi Tiga Fasa Menggunakan V/F Scalar Control
}

\author{
Abdillah Aziz Muntashir ${ }^{1}$, Era Purwanto ${ }^{2}$, Syechu Dwitya Nugraha ${ }^{3}, \mathrm{R}$ Akbar Nur Apriyanto ${ }^{4}$, \\ Hanif Hasyier Fakhruddin ${ }^{5}$ \\ 1,2,3,4,5 Jurusan Teknik Elektro, Politeknik Elektronika Negeri Surabaya \\ abdillahaziz6@gmail.com
}

\begin{abstract}
Abstrak - Motor induksi 3 fasa merupakan motor arus bolak balik yang sering digunakan pada dunia industri. Motor induksi 3 fasa memiliki beberapa kelemahan, salah satunya adalah karakteristik parameternya yang tidak linier, sehingga tidak dapat mempertahankan kecepatannya secara konstan bila terjadi perubahan beban. Untuk mengatasi masalah tersebut, digunakan sistem pengaturan logika fuzzy dengan memakai Sugeno fuzzy model. Dengan menggunakan sistem tersebut diharapkan pengaturan kecepatan motor induksi dapat mencapai kondisi steady state meskipun mengalami perubahan nilai beban. Inverter 3 fasa dalam system, menggunakan metode sinusoidal pulse width modulation (SPWM). Dalam mengoptimalkan pengaturan kecepatan motor induksi 3 fasa digunakan scalar control atau disebut juga dengan pengaturan tegangan/ frekuensi (v/f). Penggunaan scalar control dengan memaksa motor memiliki hubungan yang konstan antara tegangan dan frekuensi, mampu menjaga besarnya fluks dan nilai torsi maksimum agar tetap konstan. Hasil simulasi menunjukkan bahwa dengan menggunakan Sugeno fuzzy model, respon kecepatan motor induksi 3 fasa dapat dengan cepat menuju keadaan steady state, dengan nilai settling time (ts) dari 0.46 detik menjadi 0.285 detik dengan steady state error sebesar $0 \%$ saat set point $1200 \mathrm{rpm}$.
\end{abstract}

Kata kunci: Motor induksi 3 fasa, scalar control, Sugeno fuzzy model.

\section{Pendahuluan}

Motor induksi merupakan motor listrik arus bolak balik yang sering dijumpai dalam kehidupan sehari-hari baik di industri maupun di rumah tangga. Motor induksi 3 fasa banyak digunakan di bidang industri karena harganya relatif murah untuk bidang industri dan mempunyai kehandalan yang tinggi. Selain itu, efisiensi motor induksi 3 fasa relatif tinggi pada keadaan normal dan tidak memerlukan biaya perawatan yang besar. Namun motor induksi 3 fasa memiliki beberapa kelemahan yaitu: tidak dapat mempertahankan kecepatannya secara konstan bila terjadi perubahan beban, arus starting motor induksi 3 fasa biasanya 10 - 12 kali dari arus nominalnya, serta kecepatan motor yang sulit diatur. Oleh karena itu untuk mendapatkan kecepatan yang konstan dan performansi sistem yang lebih baik terhadap perubahan beban dibutuhkan suatu sistem pengaturan [1].

Beberapa pengaturan kecepatan motor induksi 3 fasa memiliki kelemahan. Pada pengaturan kecepatan motor induksi 3 fasa dengan mengatur frekuensinya saja, kecepatan motor induksi 3 fasa dapat diatur kecepatannya sesuai dengan frekuensinya tetapi semakin besar nilai frekuensinya torsi yang didapatkan pada motor tersebut akan turun.

Pada pengaturan kecepatan motor induksi 3 fasa dengan mengatur tegangan sumber, kecepatan motor induksi 3 fasa dapat diatur apabila dalam keadaan berbeban, torsi yang dihasilkan motor semakin besar dengan semakin besarnya tegangan sumber. Tetapi dengan mengatur tegangan sumber yang terlalu besar dapat mengakibatkan terjadinya fenomena saturasi pada fluks.

Pengontrol kecepatan motor induksi 3 fasa dilakukan dengan scalar control atau biasa disebut juga pengaturan tegangan/frekuensi (v/f). Prinsip dari kontrol skalar ini adalah memaksa motor memiliki hubungan yang konstan antara tegangan dan frekuensi. Keuntungan menggunakan kontrol skalar ini memiliki struktur kendali yang sederhana, mudah dan cepat diprogram serta dapat dioperasikan dengan metode kendali loop terbuka tanpa pengendali kecepatan atau dengan pengendali kecepatan, sehingga secara ekonomis lebih murah. Metode scalar control dapat mengatasi kelemahan pada pengaturan kecepatan motor induksi yaitu arus starting pada motor tidak terlalu besar pada frekuensi rendah. Selain itu, dengan menjaga perbandingan antara besarnya tegangan stator (magnitude) terhadap frekuensi $(\omega)$ agar selalu bernilai konstan, maka fluks dan torsi maksimum selalu konstan., sehingga dapat mencegah terjadinya saturasi fluks.

Penggunaan sistem fuzzy logic controller $(F L C)$ dalam kinerjanya sangatlah baik dengan tingkat respon yang cepat dalam mengatasi kinerja sistem kontrol yang mengalami perubahan beban. Penggunaan FLC adalah untuk intisipasi atau memperbaiki kesalahan (error) yang terjadi pada sistem (plant) yang diakibatkan oleh adanya perubahan beban. Pada penelitian ini dirancang suatu pengaturan kecepatan motor induksi 3 fasa dengan menggunakan fuzzy logic controller dengan metode Sugeno fuzzy model. Dengan adanya pengaturan kecepatan ini diharapkan kecepatan motor induksi dapat konstan sesuai yang diinginkan, walaupun terjadi perubahan beban, sehingga menghasilkan performansi motor induksi yang tinggi.

\section{METODE}

Proses penelitian terbagi menjadi beberapa tahap yang dilakukan berdasarkan urutan dalam melakukan penelitian, seperti ditunjukkan pada Gambar 1. 


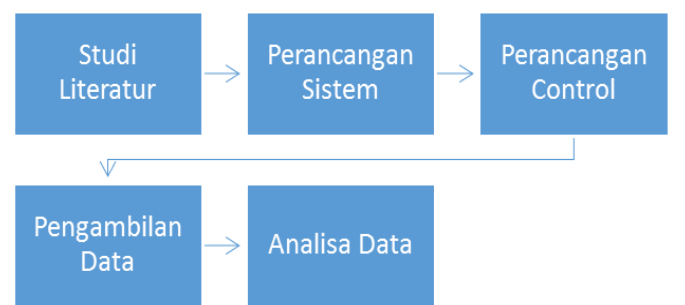

Gambar 1. Blok diagram penelitian

\section{A. Studi Literatur}

Dalam mengerjakan perencanaan simulasi, telah dipelajari literatur dari buku, jurnal, paper dan sumber lainnya tentang pengaturan kecepatan motor induksi 3 fasa dengan metode v/f scalar control menggunakan fuzzy logic controller. Hal-hal yang telah dipelajari dituliskan berikut ini.

\section{1). Motor Induksi Tiga Fasa}

Motor induksi merupakan motor yang dicatu oleh arus AC pada statornya secara langsung dan pada rotornya dengan imbas atau induksi dari stator. Ada juga yang berpendapat bahwa motor induksi merupakan motor arus AC yang paling luas digunakan. Penamaannya berasal dari kenyataan bahwa arus rotor motor diperoleh dari arus yang terinduksi sebagai akibat adanya perbedan relatif antara putaran rotor dengan medan putar (rotating magnetic field) yang dihasilkan oleh arus stator [2].

Berdasarkan dua pernyataan di atas dapat dikatakan bahwa motor induksi adalah motor arus AC dengan statornya dicatu langsung dari sumber tegangan $\mathrm{AC}$ dan arus rotornya merupakan imbas atau induksi dari statornya. Imbas tersebut sebagai akibat adanya perbedaan relatif antara putaran rotor dengan medan putar. Oleh karena itu motor AC dikenal dengan sebutan motor induksi. Seperti pada Gambar 2 merupakan rangkaian ekivalen dari motor induksi 3 fasa.

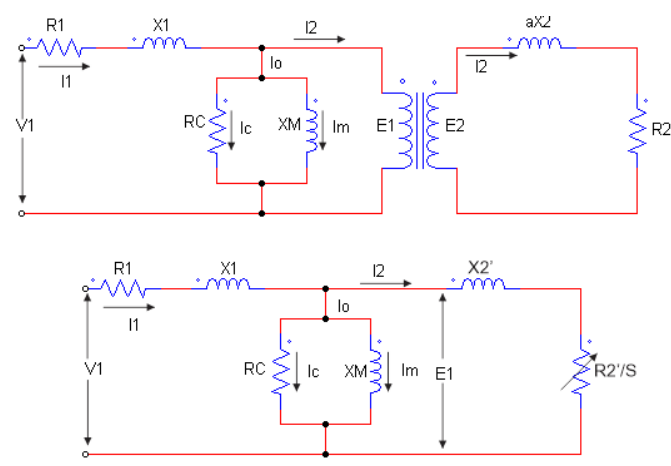

Gambar 2. Rangkaian ekivalen motor induksi 3 fasa

Sedangkan yang dimaksud dengan motor induksi 3 fasa adalah motor induksi yang pada belitan statornya dicatu dengan sumber tegangan tiga fasa yang masing-masing fasa memilki beda fasa sebesar $120^{\circ}$. Motor induksi banyak digunakan dikalangan industry. Keuntungan dan kerugian penggunaan motor induksi adalah sebagai berikut.

Keuntungan:
1. Sangat sederhana dan daya tahan kuat (konstruksi hampir tidak pernah terjadi kerusakan, khususnya tipe squirrel cage).

2. Harga relatif murah dan perawatan mudah.

3. Efisiensi tinggi. Pada kondisi berputar normal, tidak dibutuhkan sikat dan karenanya rugi daya yang diakibatkannya dapat dikurangi.

Kerugian:

1. Kecepatan tidak dapat berubah tanpa pengorbanan efisiensi.

2. Tidak seperti motor DC atau motor shunt, motor induksi tiga fasa kecepatannya akan menurun seiring dengan tambahan beban.

3. Kopel awal mutunya rendah dibandingkan dengan motor DC shunt.

\section{2). Sinusoidal Pulse Width Modulation (SPWM)}

Sinyal modulasi lebar pulsa (PWM) mengendalikan inverter saklar. Amplitudo tegangan output ditentukan oleh siklus pulsa PWM. Pola switching menghasilkan bentuk gelombang keluaran berbentuk persegi panjang yang kaya harmonik. Sifat induktif dari motor menyaring arus yang disediakan untuk menghasilkan tiga fasa gelombang sinus dengan harmonisa yang dapat diabaikan. Tujuan utama teknik modulasi adalah untuk memperoleh keluaran variabel yang memiliki komponen fundamental maksimum dengan harmonik minimum.

Teknik PWM yang biasa digunakan untuk mengontrol output tegangan inverter adalah modulasi lebar sinusoidal pulse (SPWM) dan space vector modulation (SVM). Metode paling sederhana untuk menghasilkan pulsa PWM adalah membandingkan gelombang sinus referensi daya rendah (sinyal kontrol) dengan gelombang segitiga (sinyal modulasi) yang disebut PWM sinusoidal. Konsep dasar SPWM telah diilustrasikan dalam Gambar 3.

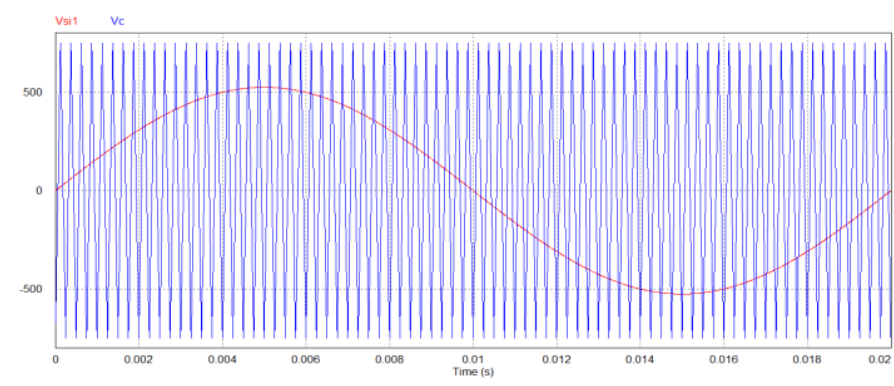

Gambar 3. Konsep dasar SPWM

Rasio modulasi frekuensi mf didefinisikan sebagai rasio frekuensi sinyal carrier dan sinyal referensi dengan persamaan sebagai berikut:

$m f=\frac{f_{\text {carrier }}}{f_{\text {reference }}}=\frac{f_{\text {tri }}}{f_{\text {sine }}}$ 
Rasio modulasi amplitudo ma. Rasio modulasi amplitudo didefinisikan sebagai rasio amplitudo dari referensi dan sinyal carrier dengan persamaan sebagai berikut:

$m a=\frac{V_{\text {reference }}}{V_{\text {carrier }}}=\frac{V_{\text {sine }}}{V_{\text {tri }}}$

Jika $m_{a} \leq 1$, amplitudo frekuensi dasar dari

tegangan output V1 secara proporsional linier terhadap $\mathrm{m}_{\mathrm{a}}$, yaitu:

$\mathrm{V}_{1}=\mathrm{m}_{\mathrm{a}} \times \mathrm{V}_{\mathrm{DC}}$

Amplitudo frekuensi dasar dari output PWM dikendalikan oleh $\mathrm{m}_{\mathrm{a}}$. Hal ini penting pada kasus tegangan supply DC yang tidak diregulasi, karena nilai $\mathrm{m}_{\mathrm{a}}$ dapat diatur untuk mengimbangi variasi pada tegangan supply DC, sehingga menghasilkan output amplitudo yang konstan. Selain itu, $\mathrm{m}_{\mathrm{a}}$ bisa divariasi untuk merubah amplitudo output. Jika $\mathrm{m}_{\mathrm{a}}$ lebih besar dari 1 , amplitude output meningkat sesuai dengan $\mathrm{m}_{\mathrm{a}}$, tetapi tidak linier atau disebut kondisi overmodulation [3].

\section{B. Perancangan Sistem}

Pengaturan kecepatan motor induksi dilakukan secara loop tertutup dengan nilai set point kecepatan yang menjadi nilai referensi kecepatan putaran pada motor. Diagram blok dari sistem pengaturan kecepatan pada motor induksi tiga fasa tersebut ditunjukkan pada Gambar 4. Pada block diagram sistem, merupakan suatu sistem pengaturan kecepatan motor induksi 3 fasa menggunakan Fuzzy Logic Controller dengan Sugeno model sebagai kontrolernya. Sumber motor induksi 3 fasa didapatkan pada inverter 3 fasa yang mengubah tegangan searah menjadi tegangan bolak balik

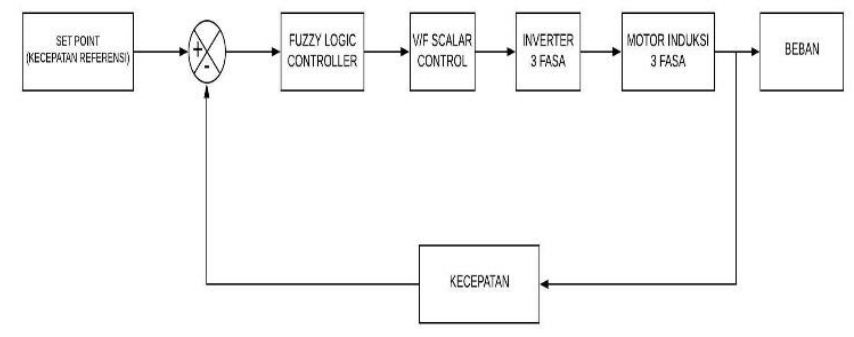

Gambar 4. Blok diagram sistem

Inverter 3 fasa yang digunakan menggunakan teknik switching sinusoidal pulse width modulation (SPWM) di mana akan menghasilkan tegangan keluaran yang termodulasi. Keluaran yang dihasilkan dari inverter tersebut yaitu sebesar 220 Vrms sesuai dari tegangan nominal motor, nantinya keluaran tegangan tersebut digunakan sebagai supply motor induksi 3 fasa, motor induksi 3 fasa yang digunakan pada simulasi memiliki spesifikasi $1.5 \mathrm{Hp}$ atau setara dengan $1.2 \mathrm{KW}$ dengan memiliki kecepatan nominal sebesar 1435 RPM. Untuk melakukan pengaturan kecepatan motor induksi 3 fasa digunakan fuzzy logic controller. Metode yang digunakan pada fuzzy logic controller pada sistem ini menggunakan metode Sugeno.

Metode Sugeno hampir sama dengan metode Mamdani, hanya saja output (konsekuen) sistem tidak berupa himpunan fuzzy, melainkan berupa konstanta atau persamaan linear. Di mana terdapat 2 input yaitu error dan delta error dan 1 output fungsi keanggotaan. Fungsi keanggotaan/MF (membership function) yang digunakan pada sistem ini yaitu $7 \times 7$. Set point yang digunakan pada pengontrolan sistem ini menggunakan set point kecepatan di mana keluaran dari sensor kecepatan akan di-feedback sehingga menghasilkan sinyal error, sinyal error dan delta error ini nantinya akan diolah oleh fuzzy logic controller. Keluaran dari control tersebut nantinya akan mengubah nilai parameter $\mathrm{mf}$ (Modulation frequency) dan ma (Modulation amplitude) setelah diproses oleh scalar control dalam menjaga rasio perbandingan tegangan dan frekuensi tetap konstan.

\section{Perancangan Control}

Perancangan control pada sistem ini terdiri dari scalar control dan fuzzy logic controller sebagai berikut:

\section{1). Scalar Control}

Kecepatan motor induksi berbanding lurus dengan frekuensi sumber daya dan jumlah kutub dari motor. Karena jumlah kutub ditetapkan melalui desain, cara terbaik untuk merubah kecepatan dari motor induksi tersebut adalah dengan merubah frekuensi sumber daya. Torsi yang dihasilkan oleh motor induksi adalah berbanding lurus dengan rasio tegangan yang diberikan dan frekuensi sumber daya. Dengan merubah tegangan dan frekuensi, tetapi menjaga konstan rasio keduanya, torsi yang dihasilkan dapat dijaga konstan sepanjang daerah pengaturan kecepatan. Kendali ini disebut sebagai kendali $v / f$ constan. Oleh karena itu dengan memvariasikan tegangan dan frekuensi oleh rasio yang sama, torsi dapat dijaga konstan dan independen frekuensi suplai di seluruh rentang kecepatan [4].

$\mathrm{V}_{\mathrm{eff}} \propto f . \varphi \Rightarrow \varphi \propto \frac{V}{f}$

Di mana $\mathrm{V}$ dan $\varphi$ adalah tegangan stator dan fluks masingmasing serta $f$ adalah frekuensi tegangan input. Ini membuat $v / f$ konstan adalah pengaturan kecepatan paling umum motor induksi [4]. Seperti pada Gambar 5.

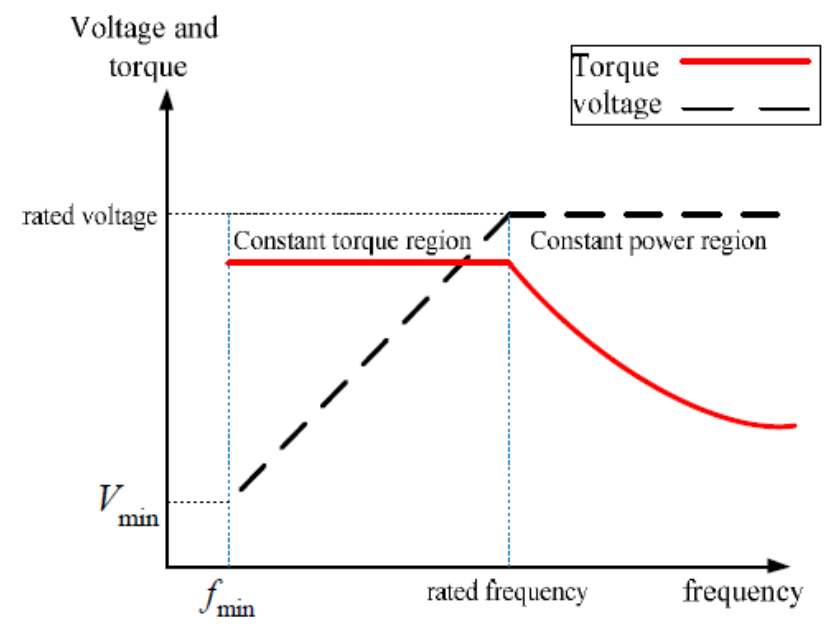

Gambar 5. Karakteristik v/f konstan 
Pengaturan kecepatan motor induksi dilakukan oleh mempertahankan rasio $v / f$ yang konstan untuk menghindari celah udara variasi fluks. Seperti yang ditunjukkan pada Gambar 5, tujuan dari pengaturan $v / f$ konstan adalah untuk menjaga torsi konstan dan independen frekuensi, mencapai efisiensi yang lebih tinggi dan arus yang lebih rendah saat runtime [4].

\section{2). Fuzzy Logic Controller (FLC)}

Kontroler logika fuzzy dikategorikan dalam kontrol cerdas (intelligent control). Unit logika fuzzy memiliki realibity yang mampu menyelesaikan masalah perilaku sistem yang kompleks dan memiliki ketidakpastian [5]. Pengendali logika fuzzy memiliki unjuk kerja sangat baik dibandingkan dengan sistem kontroler PID. Berbeda dengan sistem kontrol biasa, keluaran yang dihasilkan diolah dan didefinisikan secara pasti atau dengan istilah lain hanya mengenal logika ' 0 ' dan ' 1 ' atau bekerja pada daerah ON dan OFF sehingga didapatkan perubahan yang kasar. Pada sistem logika fuzzy, nilai yang berada antara ' 0 ' dan ' 1 ' dapat didefinisikan, sehingga kontroler dapat bekerja seperti sistem syaraf manusia yang bisa merasakan lingkungan eksternalnya, yakni "kurang", "agak", "biasa", dan "sangat" [6]. Kontroller yang berbasis logika fuzzy harus melalui beberapa tahapan sebelum sampai ke plant. Tahapan-tahapan tersebut kuantisasi, fuzzifikasi, penentuan rule base dan inference (reasoning), kemudian defuzzifikasi. Metode sistem inferensi fuzzy (fuzzy inference system/FIS) yang dikenal antara lain metode: Mamdani, Sugeno dan Tsukamoto [7].

Blok diagram fuzzy logic controller simulink menggunakan matlab sistem pengaturan kecepatan motor induksi menggunakan metode v/f scalar control dengan kontroler logika fuzzy yang dirancang, ditunjukkan pada Gambar 6.

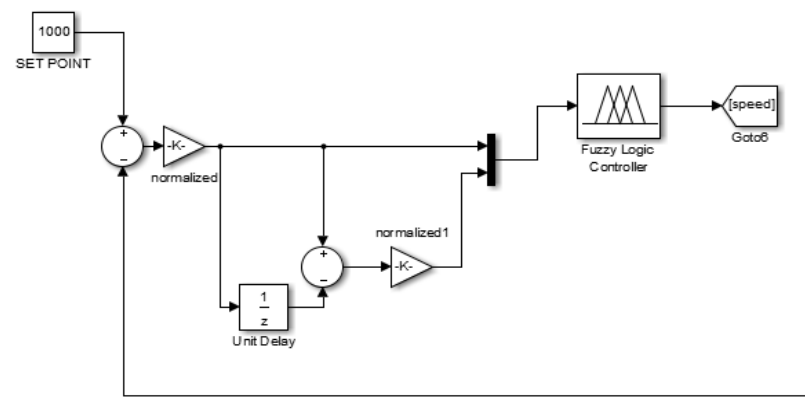

Gambar 6. Blok diagram Simulink FLC

Pada pengontrol fuzzy logic controller memiliki dua masukan dan satu keluaran yang masing-masing memiliki 7 fungsi keanggotaan. Masukan pada control fuzzy ini adalah error (e) dan delta error (de), sedangkan keluaran pengontrol fuzzy merupakan sinyal control $f(\mathrm{u})$. Metode yang digunakan yaitu sugeno fuzzy models. Metode Sugeno hampir sama dengan penalaran mamdani, hanya saja output (konsekuen) sistem tidak berupa himpunan Fuzzy, melainkan berupa konstanta atau persamaan linear.

Menggunakan fuzzy inference system (FIS) model Sugeno, maka blok FIS editor dari Simulink/Matlab dapat dirancang seperti tampilan Gambar 7. Metode yang digunakan pada kontroler logika fuzzy ini adalah metode statik, artinya sifat fungsi keanggotaan (membership function/MF) bekerja dengan rentang kerja (range) tetap, yaitu antara 0 sampai dengan 4 untuk variabel input, dan antara 0 sampai dengan 4 untuk variabel output. Seperti pada Gambar 8 dan Gambar 9.

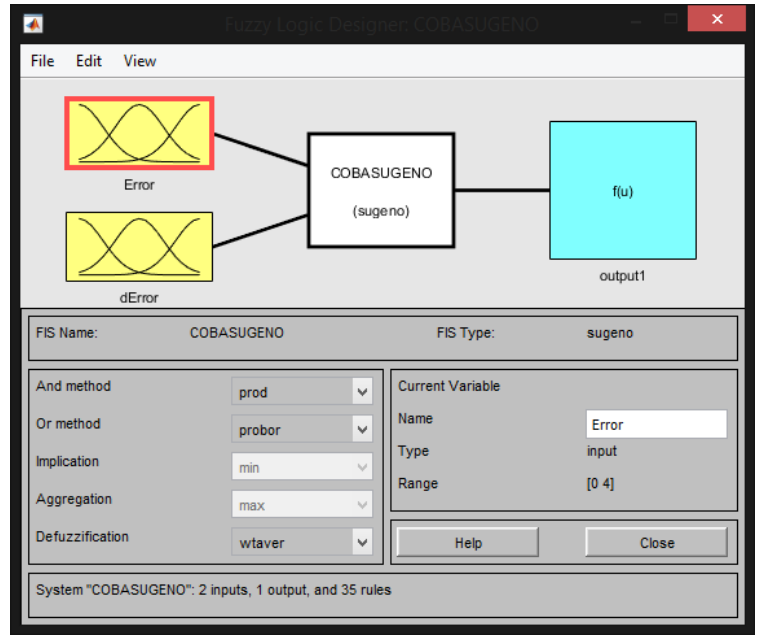

Gambar 7. Block FIS model Sugeno

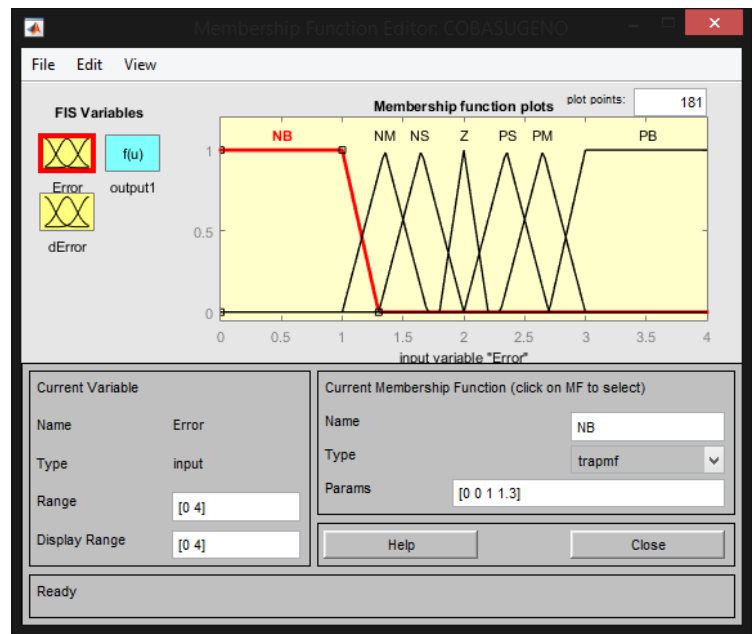

Gambar 8. Block MF variable input "error”

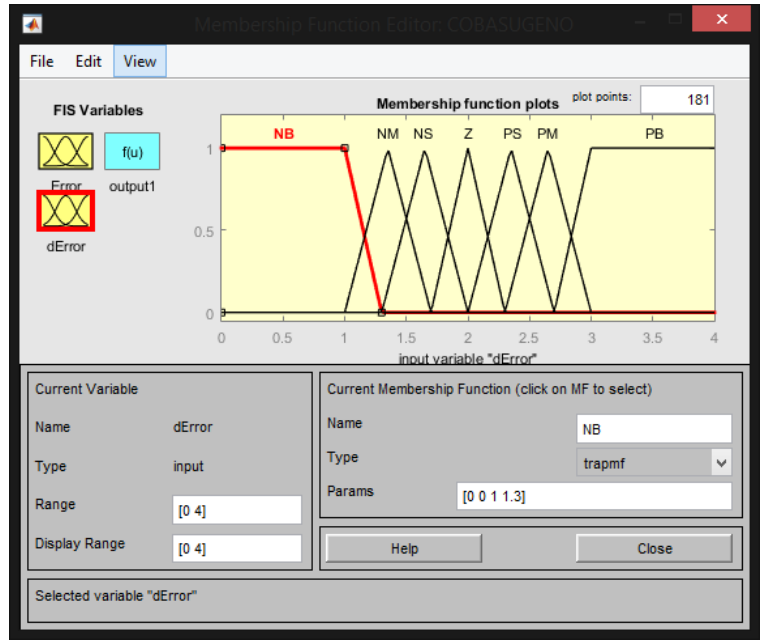

Gambar 9. Block MF variable input "delta error"

Submitted: 07/10/2020; Revised: 07/12/2020; 
Dalam merancang kontroler logika fuzzy yang perlu diperhatikan adalah variabel input (masukan) error (e) dan perubahan / delta error (De), dinyatakan melalui persamaan:

$$
\begin{aligned}
& \mathrm{e}(\mathrm{k})=\mathrm{sp}-\mathrm{y}(\mathrm{k}) \\
& \mathrm{De}(\mathrm{k})=\mathrm{e}(\mathrm{k})-\mathrm{e}(\mathrm{k}-1)
\end{aligned}
$$

Di mana sp adalah setpoint (kecepatan referensi 'w-ref') dan y adalah keluaran (output) sistem, sedangkan k dan k-1 adalah kejadian urutan dari pencuplikan data sistem [8]. Pada kasus pengaturan kecepatan motor induksi, himpunan semesta pembicaraan meliputi error kecepatan dan delta error kecepatan dinyatakan melalui persamaan (5) dan (6).

Error dan delta error yang terjadi selama sistem dioperasikan terlebih dahulu dikuantisasi atau dipetakan melalui interpolasi biasa menjadi error terkuantisasi (Qe) dan delta error terkuantisasi (dQe). Pengkuantisasian melalui interpolasi bertujuan untuk memetakan error dan delta error ke dalam semesta pembicaraan dengan rentang kerja yang telah ditetapkan di atas.

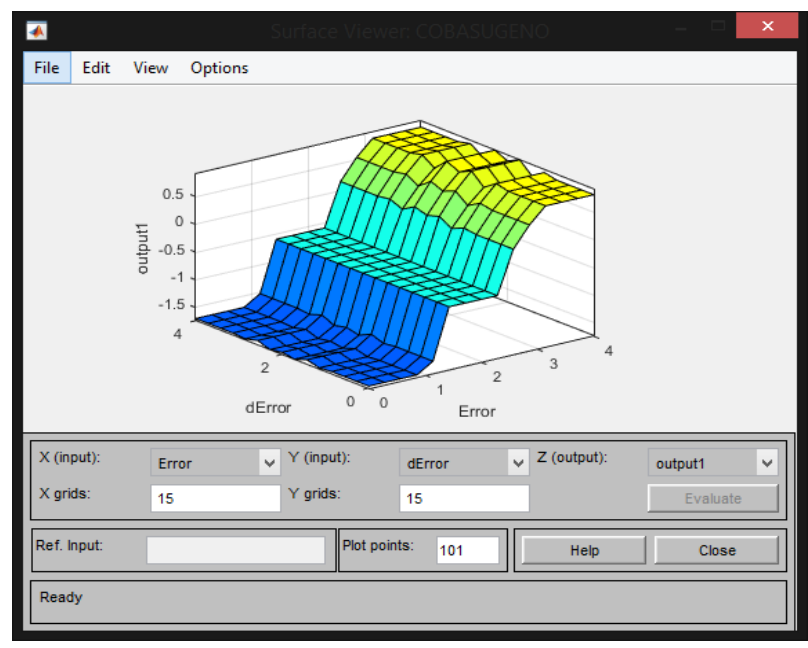

Gambar 10. Blok MF variable output

TABEL 1

RULE BASE

\begin{tabular}{cccccccc} 
& NB & NM & NS & $\mathbf{Z}$ & PS & PM & PB \\
\hline NB & NB & NB & NB & NB & NM & NS & ZE \\
NM & NB & NB & NB & NM & NS & ZE & PS \\
NS & NB & NB & NM & NS & ZE & PS & PM \\
$\mathbf{Z}$ & NB & NM & NS & ZE & PS & PM & PB \\
PS & NM & NS & ZE & PS & PM & PB & PB \\
PM & PS & PS & PS & PS & PS & PS & PS \\
PB & PM & PM & PM & PM & PM & PM & PM \\
\hline
\end{tabular}

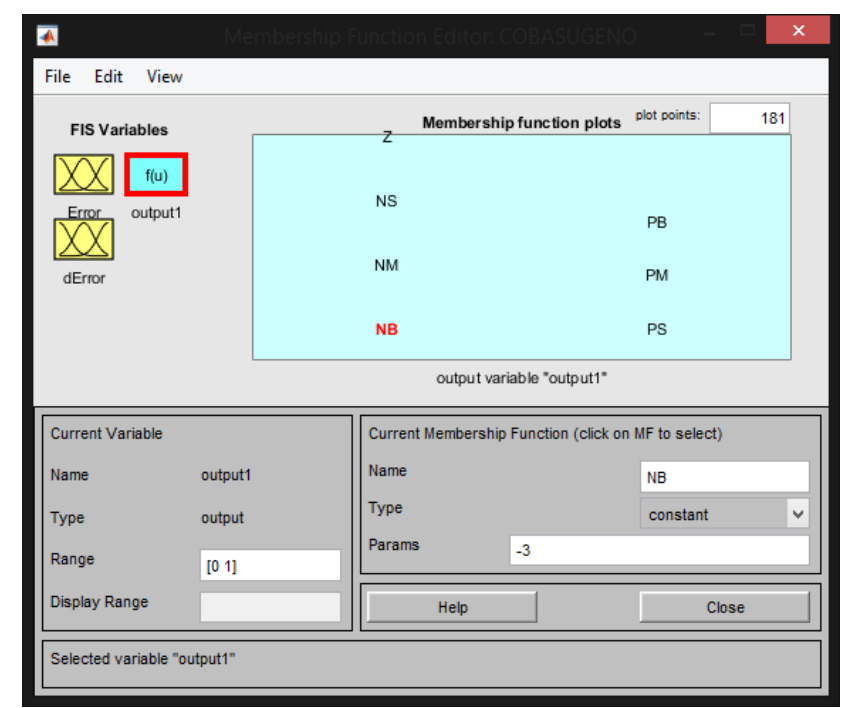

Gambar 11. Rule model surface

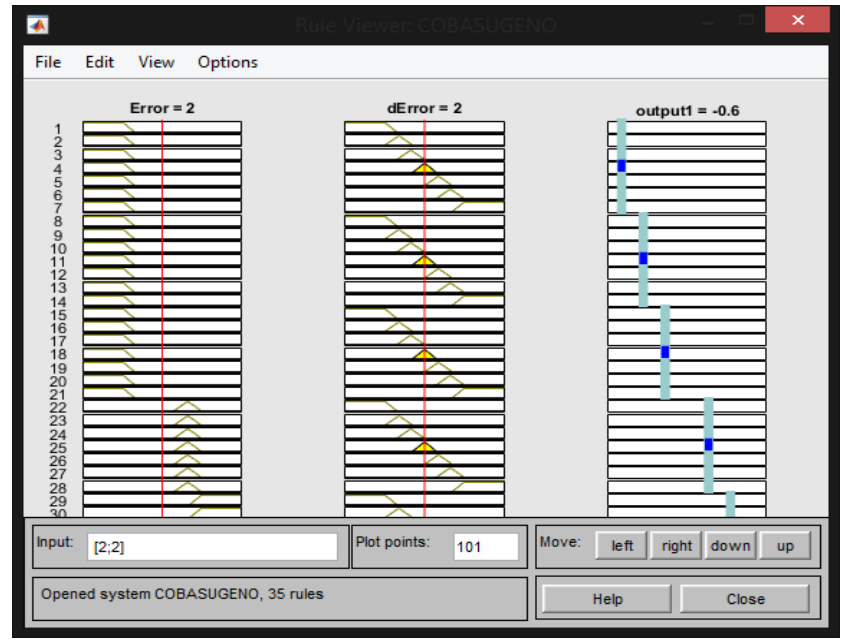

Gambar 12. Rule viewer

Aturan dasar fuzzy (rule base) dari kontroler logika fuzzy pada penelitian ini ditunjukkan pada Tabel 1 blok fuzzy rule base sedangkan pada Gambar 11 dan Gambar 12 merupakan tampilan fuzzy rule model surface dan rule viewer pada Fuzzy Inference System (FIS) fuzzy matlab.

\section{Pengambilan Data}

Pengambilan data meliputi data respon kecepatan motor open loop (tanpa pengaturan) dan respon close loop (dengan pengontrol) serta pengamatan gelombang tegangan antar fasa, arus fasa, torsi motor dan nilai total harmonic distortion (THD). Pengambilan data respon kecepatan open loop bertujuan untuk identifikasi plant atau dengan kata lain mengetahui perilaku sistem tanpa pengontrol. Pengambilan data dilaksanakan variasi nilai kecepatan yaitu nilai setpoint $800 \mathrm{rpm}, 1000 \mathrm{rpm}, 1200$ rpm. Beban yang diberikan sebesar $10 \mathrm{Nm}$ yang akan diberikan ke motor. Data yang diamati berupa respon kecepatan motor tanpa menggunakan pengontrol dibandingkan dengan saat menggunakan kontrol. 


\section{E. Analisa}

Pada tahap ini dilakukan analisa data mengenai penelitian yang dilakukan. Pada laporan tersebut dijelaskan mengenai semua hal yang berkaitan tentang penelitian, seperti penjelasan tentang simulasi sistem, perencanaan sistem pengaturan, sistem kerja alat, data-data hasil simulasi, dan lain sebagainya. Diharapkan penulisan laporan tersebut dapat bermanfaat sebagai bahan acuan didalam pembuatan alat serupa pada waktu yang akan datang.

\section{HASIL DAN PEMBAHASAN}

Untuk menguji keberhasilan/ketangguhan dari sistem pengaturan yang dirancang, maka simulasi program dilakukan dengan kondisi pemberian beban (torsi beban), beban yang diberikan yaitu sebesar $10 \mathrm{Nm}$ yang didasari pada beban penuh. Pada masing-masing kondisi perubahan set point tersebut diamati dan dianalisis kinerja motor induksi seperti overshoot, undershoot, rise time, settling time dan steady state error melalui tampilan karakteristik kecepatan motor induksi pada blok "Scope" matlab. Gambar 13 merupakan diagram sirkuit pengendali motor induksi 3 fasa menggunakan fuzzy logic controller menggunakan matlab.

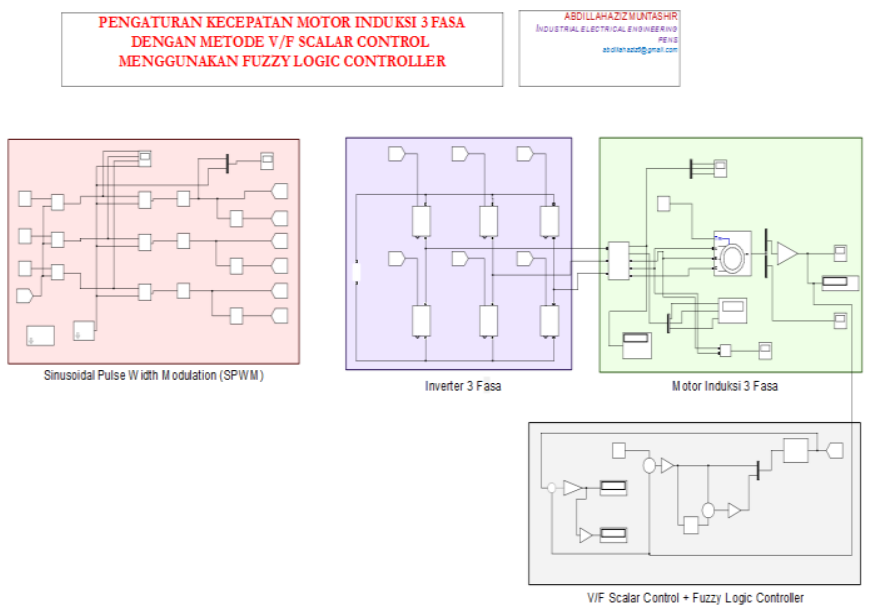

Gambar 13. Diagram sirkuit sistem dengan Simulink Matlab

Sinyal pembangkitan inverter 3 fasa mengunakan sinusoidal pulse width modulation (SPWM) dibangkitkan dengancara membandingkan sinyal referensi yaitu sinyal sinusoidal dengan sinyal carrier yaitu sinyal segitiga. Sinyal referensi memiliki perbedaan sudut 120 untuk mewakili sumber 3 fasa yang memiliki beda sudut fasa 120. Keluaran dari komparator atau pembanding sinyal tersebut digunakan sebagai pembangkitan sinyal inverter 3 fasa pada komponen switching IGBT di mana sinyal pembangkitan tersebut terdiri dari sinyal high dan sinyal low. Sinyal tersebut nantinya akan men-drive dari 6 IGBT pada inverter 3 fasa. Blok diagram sirkuit sinusoidal pulse width modulation (SPWM) menggunakan simulink Matlab seperti pada Gambar 14.

Blok inverter 3 fasa pada Gambar 15, terdiri dari 6 IGBT (komponen switching) di mana sinyal pembangkitan pada kaki gate didapatkan pada proses pembangkitan sinyal SPWM.
Besarnya tegangan input $\mathrm{DC}\left(\mathrm{V}_{\mathrm{DC}}\right)$ sebesar $311.12 \mathrm{~V}$ supaya menghasilkan tegangan keluaran inverter sebesar 220 Vrms sehingga bisa digunakan sebagai sumber dari motor induksi 3 fasa.

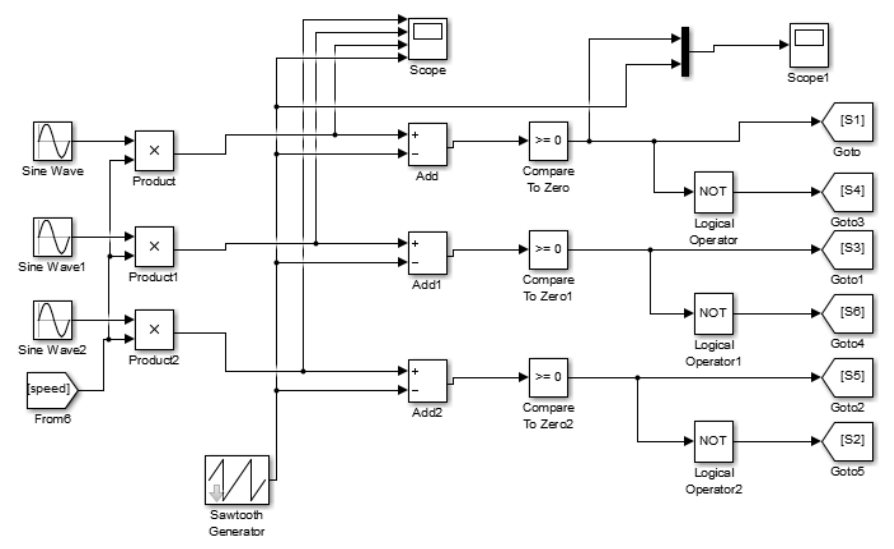

Gambar 14. Diagram sirkuit sinusoidal pulse width modulation

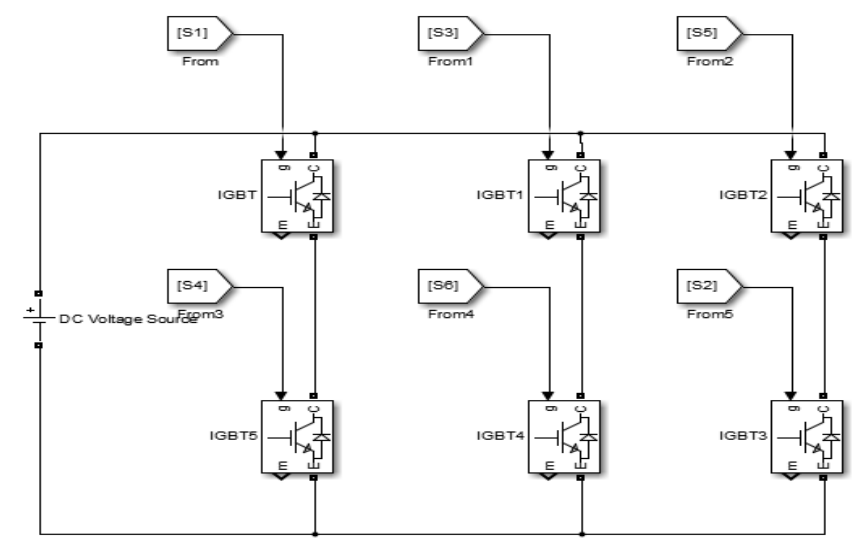

Gambar 15. Diagram sirkuit inverter 3 fasa

Pada simulasi ini motor induksi yang digunakan memiliki kapasitas 1.5 HP atau setara dengan 1.2 KW dengan tegangan nominal motor sebesar 220 Vrms. Pada Tabel 2 merupakan spesfikasi dari motor induksi 3 fasa yang digunakan pada simulasi ini.

TABEL 2

SPESIFIKASI MOTOR INDUKSI 3 FASA

\begin{tabular}{lccc}
\hline No & Parameter & Nilai & Satuan \\
\hline 1 & $\mathrm{R}_{\text {stator }}$ & 5.27 & $\Omega$ \\
2 & $\mathrm{R}_{\text {rotor }}$ & 3.40 & $\Omega$ \\
3 & $\mathrm{~L}_{\text {stator }}$ & 4.33 & $\mathrm{mH}$ \\
4 & $\mathrm{~L}_{\text {rotor }}$ & 4.46 & $\mathrm{mH}$ \\
5 & L $_{\text {magnetisasi }}$ & 270 & $\mathrm{mH}$ \\
6 & Daya (P) & 1,5 & $\mathrm{HP}$ \\
7 & V L-L (rms) $_{\text {L }}$ & 220 & Volt \\
8 & Frekuensi & 50 & $\mathrm{~Hz}$ \\
9 & Pole & 4 & unit \\
10 & Kecepatan motor & 1435 & $\mathrm{Rpm}$ \\
\hline
\end{tabular}

Pada blok motor induksi 3 fasa memiliki tiga input yaitu A, B, C. Ketiga input ini merupakan output dari blok inverter 3 fasa. Spesifikasi dari motor induksi 3 fasa seperti pada Tabel 2. 
Besarnya torsi beban yang diberikan yaitu sebesar $10 \mathrm{Nm}$. Parameter yang diambil dari blok tersebut yaitu rotor speed dan electromagnetic torque, di mana rotor speed digunakan sebagai feedback atau input dari sebuah controller. Block controller pada Gambar 16 merupakan blok keseluruhan kontroler yaitu terdiri dari v/f scalar control dan fuzzy logic controller. Pada block scalar control parameter yang diamati yaitu frekuensi (f) dan modulation amplitude (ma). Besarnya nilai rasio perbandingan $\mathrm{v} / \mathrm{f}$ sebesar 220/50 sehingga didapatkan 4.4.

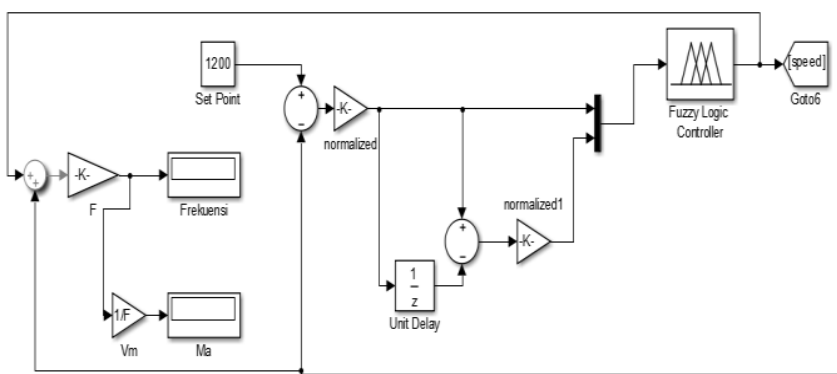

Gambar 16. Diagram sirkuit kontroler

Gambar 17 dan Gambar 18 merupakan gambar gelombang tegangan output $\mathrm{V}_{\mathrm{L}-\mathrm{L}}$ dan gelombang arus output $\mathrm{I}_{\mathrm{L} \text { - }}$ L keluaran dari inverter 3 fasa yang terhubung ke motor induksi 3 fasa dengan torsi beban sebesar $10 \mathrm{Nm}$.

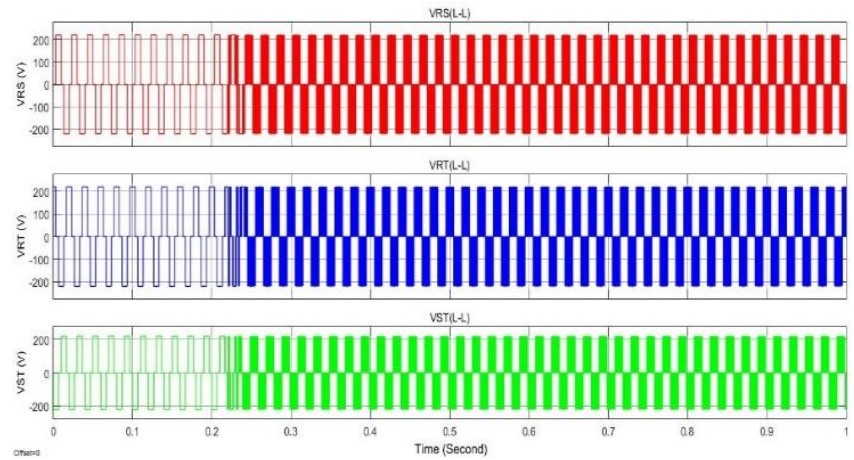

Gambar 17.Tegangan output $\mathrm{V}_{\mathrm{L}-\mathrm{L}}$
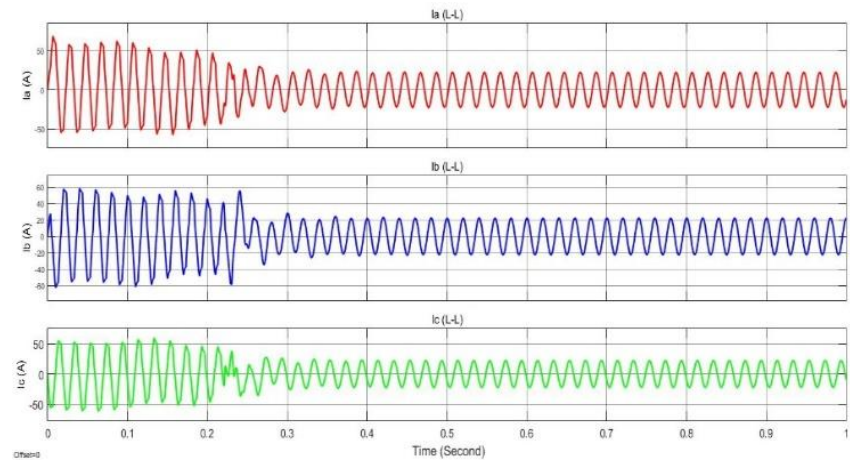

Gambar 18. Arus output $\mathrm{I}_{\mathrm{L}-\mathrm{L}}$

Respon kecepatan motor induksi 3 fasa yang didapatkan pada saat kondisi open loop dengan nilai set point $800 \mathrm{rpm}$, $1000 \mathrm{rpm}, 1200 \mathrm{rpm}$ dapat dilihat pada Gambar 19, Gambar 20, dan Gambar 21 dengan torsi beban sebesar $10 \mathrm{Nm}$.

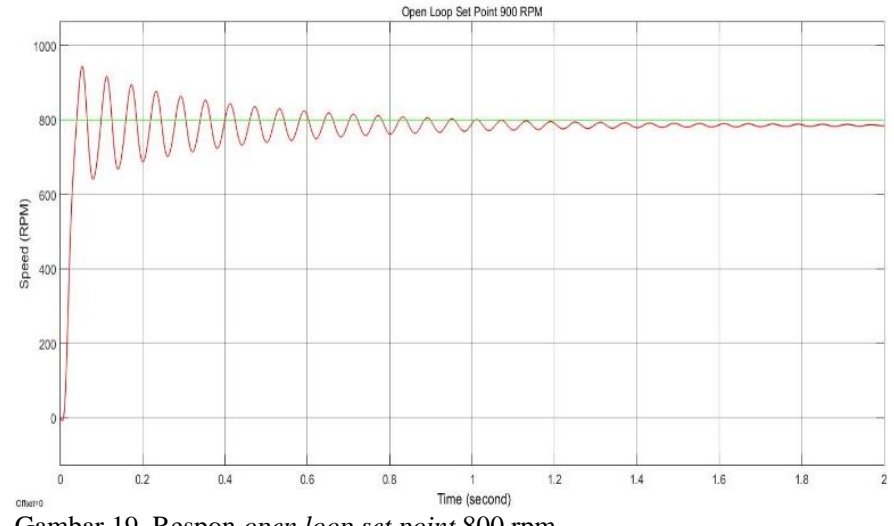

Gambar 19. Respon open loop set point $800 \mathrm{rpm}$

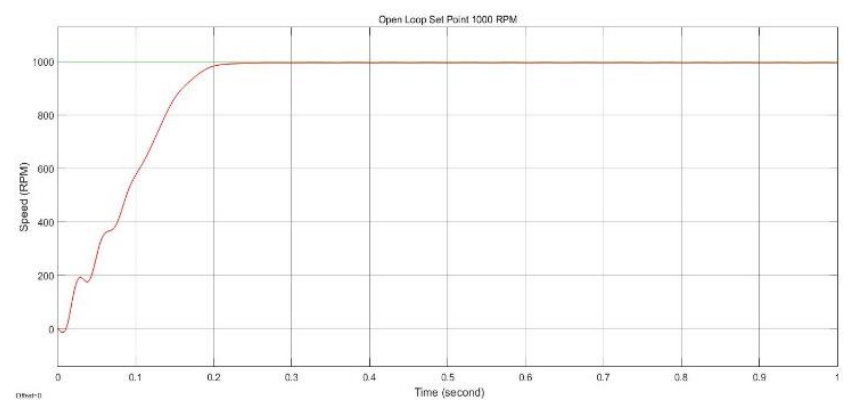

Gambar 20. Respon open loop set point $1000 \mathrm{rpm}$

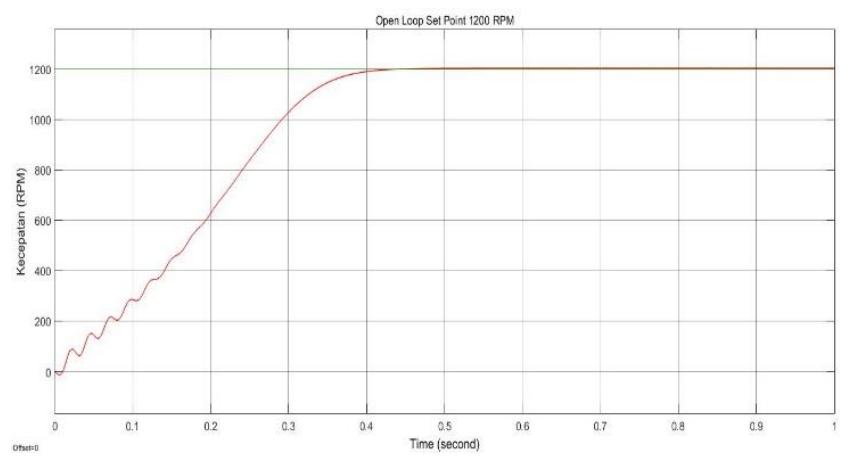

Gambar 21. Respon open loop set point $1200 \mathrm{rpm}$

Gambar 19, Gambar 20, dan Gambar 21 menunjukkan respon open loop kecepatan motor induksi 3 fasa dengan variasi nilai set point kecepatan. Pada saat set point $800 \mathrm{rpm}$ didapatkan respon dengan nilai rise time $0.15 \mathrm{~s}$, setling time $2.2 \mathrm{~s}$. dan steady state error sebesar $2.062 \%$. Pada saat set point $1000 \mathrm{rpm}$ didapatkan respon dengan nilai rise time $0.165 \mathrm{~s}$, settling time 0.27 s. dan steady state error sebesar $0.5 \%$. Pada saat set point $1200 \mathrm{rpm}$ didapatkan respon dengan nilai rise time $0.31 \mathrm{~s}$, settling time $0.46 \mathrm{~s}$. dan steady state error sebesar $0.416 \%$. Settling time merupakan waktu yang ditempuh motor hingga menuju ke keadaan steady state. Sedangkan rise time merupakan waktu yang menyatakan bahwa respon sistem telah naik dari $10 \%$ ke $90 \%$ dari nilai respon pada keadaan steady state. Dengan nilai settling time dan rise time yang didapatkan tersebut tergolong mempunyai respon yang kurang bagus atau lambat dalam menuju ke keadaan steady state, sehingga diperlukan sebuah pengontrol untuk memperbaiki respon tersebut.

Submitted: 07/10/2020; Revised: 07/12/2020;

Accepted: 27/12/2020; Online first: 31/12/2020

http://dx.doi.org/10.46964/poligrid.v1i2.379 
Tabel 3 merupakan data hasil simulasi v/f scalar control tegangan output $\left(\mathrm{V}_{\mathrm{L}-\mathrm{L}}\right)$ dengan perubahan nilai set point kecepatan, sedangkan Gambar 22 menunjukkan grafik v/f konstan dari hasil tersebut.

TABEL 3

NILAI TEGANGAN OUTPUT

\begin{tabular}{|c|c|c|c|c|}
\hline RPM & $\begin{array}{l}\text { Frekuensi } \\
\quad(\mathrm{Hz})\end{array}$ & $\begin{array}{c}\text { Modulasi } \\
\text { amplitudo } \\
\text { (ma) }\end{array}$ & $\operatorname{Vrms}_{(\mathrm{L}-\mathrm{L})}(\mathrm{V})$ & $\begin{array}{c}\text { Rasio } \\
\text { V/F }\end{array}$ \\
\hline 800 & 26 & 0.5312 & 116.86 & 4.4 \\
\hline 1000 & 33 & 0.6665 & 146.63 & 4.4 \\
\hline 1200 & 40 & 0.7999 & 175.97 & 4.4 \\
\hline
\end{tabular}

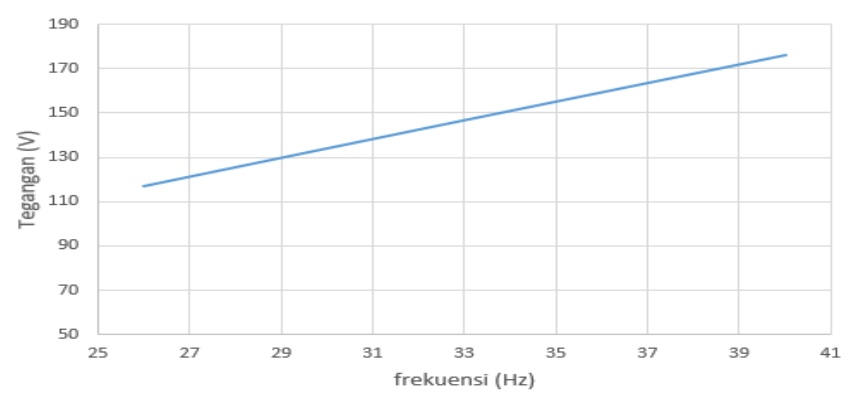

Gambar 22. Grafik V/F constan

Berdasarkan Tabel 3 dan Gambar 22, dijelaskan bahwa semakin besar nilai frekuensi atau nilai kecepatan motor (rpm), maka semakin besar nilai modulasi amplitudo $\left(\mathrm{m}_{\mathrm{a}}\right)$, sehingga nilai tegangan yang dihasilkan juga semakin besar, begitu juga sebaliknya.

Untuk memperbaiki respon dari kecepatan motor tersebut maka digunakanlah fuzzy logic controller. Metode yang digunakan yaitu Sugeno fuzzy model. Respon motor induksi 3 fasa pada saat kondisi close loop yang didapat pada nilai set point $800 \mathrm{rpm}, 1000 \mathrm{rpm}, 1200 \mathrm{rpm}$ dan torsi beban sebesar 10 Nm, dapat dilihat pada Gambar 23, Gambar 24, dan Gambar 25.

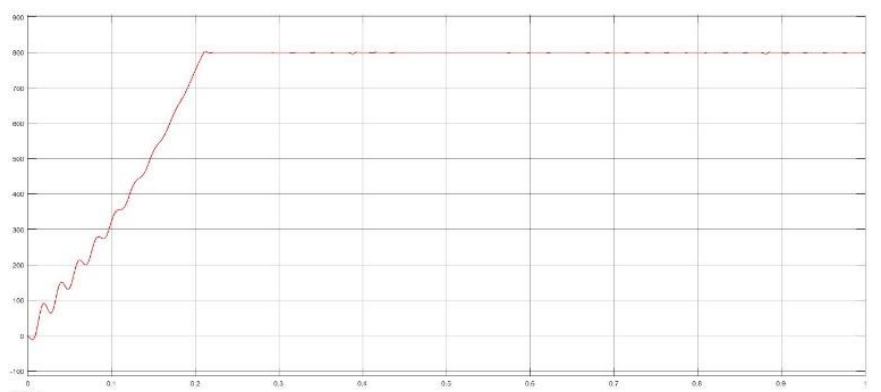

Gambar 23. Respon close loop set point $800 \mathrm{rpm}$

TABEL 4

PERBANDINGAN RESPON OPEN LOOP DENGAN CLOSE LOOP

\begin{tabular}{ccccc}
\hline Kondisi & $\begin{array}{c}\text { Set Point } \\
(\mathrm{rpm})\end{array}$ & Rise Time $(\mathrm{s})$ & $\begin{array}{c}\text { Settling Time } \\
(\mathrm{s})\end{array}$ & $\begin{array}{c}\text { Steady } \\
\text { state error } \\
(\%)\end{array}$ \\
\hline Open & 800 & 0.15 & 2.2 & 2.062 \\
Loop & 1000 & 0.165 & 0.27 & 0.5 \\
& 1200 & 0.31 & 0.46 & 0.416 \\
Close & 800 & 0.165 & 0.22 & 0 \\
Loop & 1000 & 0.195 & 0.25 & 0 \\
\hline
\end{tabular}

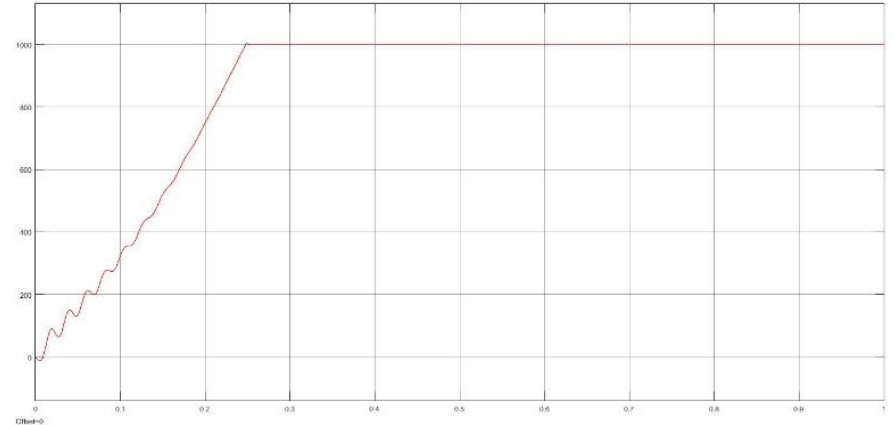

Gambar 24. Respon close loop set point $1000 \mathrm{rpm}$

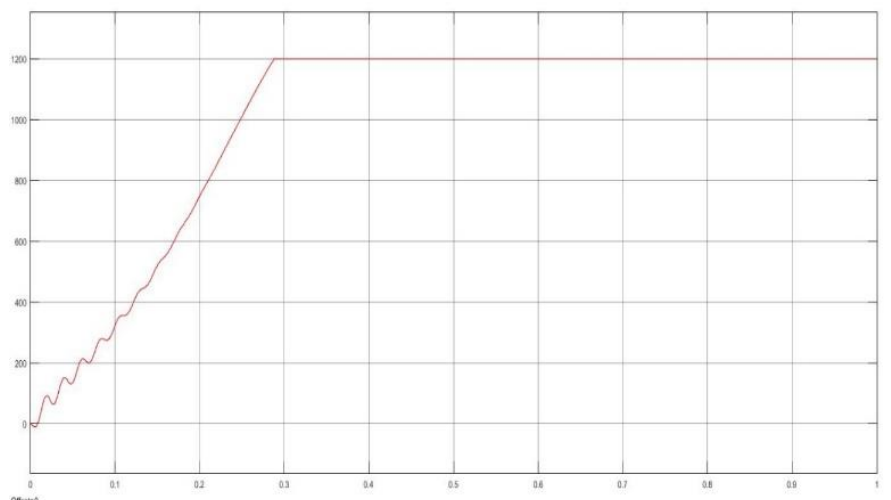

Gambar 25. Respon close loop set point $1200 \mathrm{rpm}$

Gambar 23, Gambar 24, dan Gambar 25 merupakan respon kecepatan close loop motor induksi 3 fasa dengan variasi nilai set point kecepatan. Pada saat set point 800 rpm didapatkan respon dengan nilai rise time $0.165 \mathrm{~s}$, settling time $0.22 \mathrm{~s}$. dan steady state error sebesar $0 \%$. Pada saat set point $1000 \mathrm{rpm}$ didapatkan respon dengan nilai rise time $0.195 \mathrm{~s}$, settling time $0.25 \mathrm{~s}$. dan steady state error sebesar $0 \%$. Pada saat set point $1200 \mathrm{rpm}$ didapatkan respon dengan nilai rise time $0.24 \mathrm{~s}$, settling time $0.285 \mathrm{~s}$. dan steady state error sebesar $0 \%$.

Dengan nilai settling time dan rise time yang didapatkan dengan menggunakan fuzzy logic controller, respon kecepatan menjadi lebih baik. Hal ini dikarenakan adanya peningkatan nilai rise time dan settling time atau semakin cepatnya respon kecepatan motor dalam menuju keadaan steady state. Sehingga dapat ditabelkan untuk dibandingkan kondisi saat open loop atau belum digunakannya pengontrol dengan saat close loop atau saat digunakannya fuzzy logic controller pada Tabel 4.

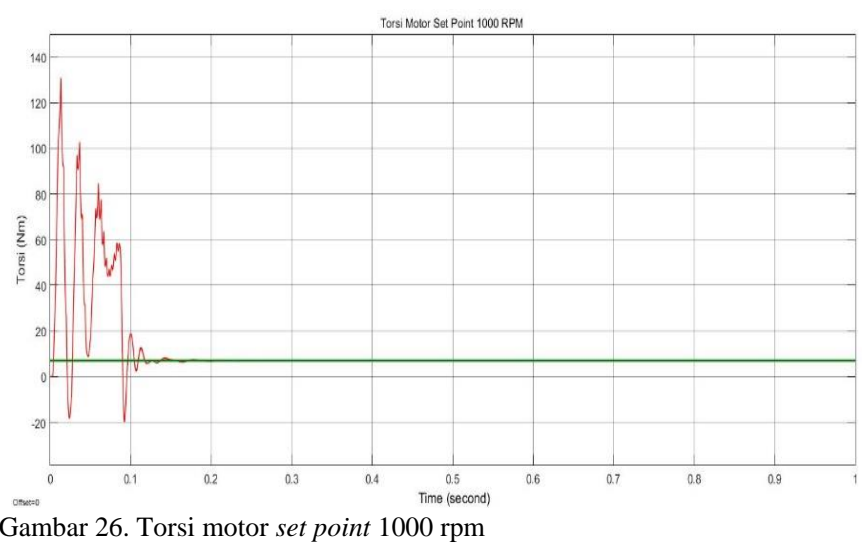

Submitted: 07/10/2020; Revised: 07/12/2020;

Accepted: 27/12/2020; Online first: 31/12/2020

http://dx.doi.org/10.46964/poligrid.v1i2.379 
Gambar 26 merupakan gambar gelombang torsi motor yang dihasilkan saat torsi beban $10 \mathrm{Nm}$ saat set point $1000 \mathrm{rpm}$, sedangkan Pada Gambar 27 dan Gambar 28 merupakan nilai total harmonic distorsion THDV dan THDI

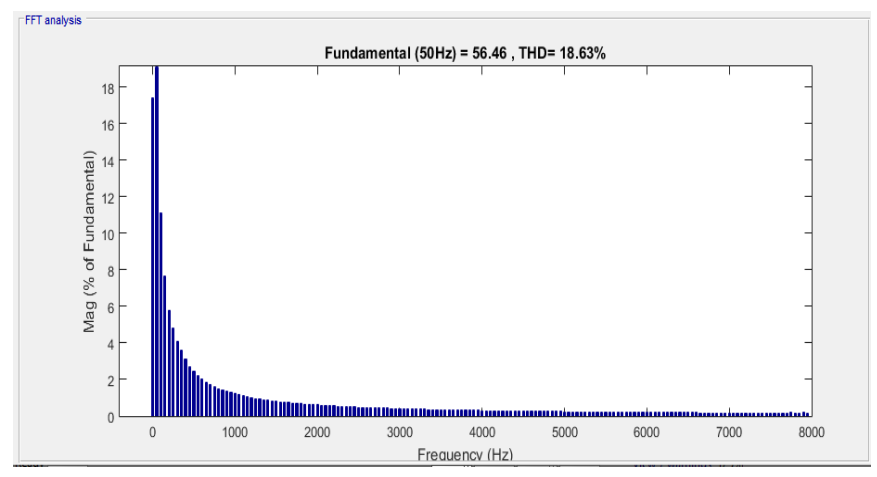

Gambar 27. THDI

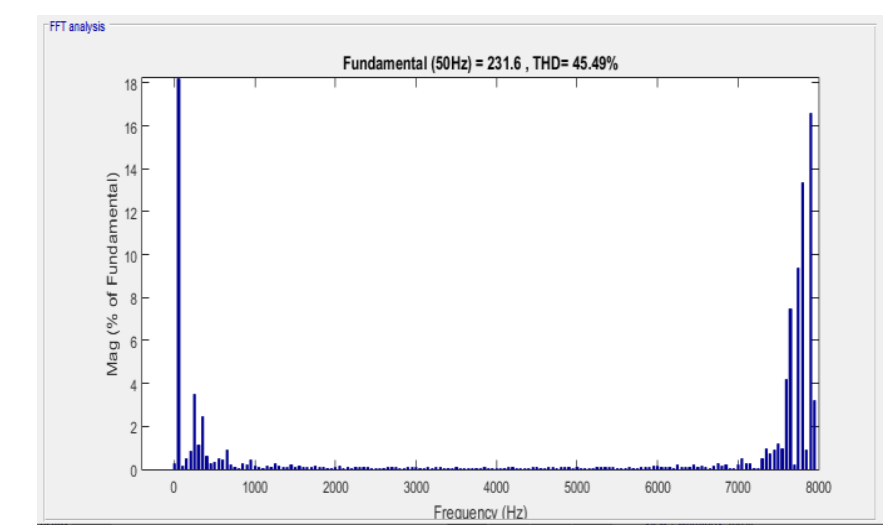

Gambar 28. THDV

Dari hasil simulasi yang didapat pada sistem tersebut memiliki kandungan harmonisa yang besar, baik THDI maupun THDV hal dikarenakan teknik switching yang digunakan pada inverter 3 fasa yaitu SPWM di mana masih tergolong memiliki kandungan harmonisa yang tinggi, selain itu beban yang digunakan yaitu motor induksi 3 fasa merupakan jenis beban non linier atau beban yang bersifat induktif sehingga memiliki kandungan harmonisa yang tinggi. Serta itu tidak digunakannya low pass filter pada keluaran inverter 3 fasa sehingga kandungan harmonisa tidak termitigasi.

\section{KESIMPULAN}

Berdasarkan simulasi yang dilakukan, maka dapat disimpulan bahwa:

1. Dengan menggunakan fuzzy logic controller metode Sugeno pada pengaturan kecepatan motor induksi 3 fasa, dengan set point kecepatan 800, 1000 dan $1200 \mathrm{rpm}$ dengan torsi beban sebesar $10 \mathrm{Nm}$ didapatkan respon yang sesuai dengan set pointnya. Dari respon yang didapatkan sistem memiliki nilai steady state error yang rendah, serta nilai rise time dan settling time yang cepat sehingga motor cepat dalam menuju keadaan steady state.
2. Pada sistem ini nilai total harmonic distorsion THDV dan THDI, dari hasil simulasi yang didapatkan memiliki kandungan harmonisa yang besar, yaitu THDV sebesar $45.49 \%$ sedangkan THDI sebesar $18.63 \%$.

\section{REFERENSI}

[1] R.I. Putri, "Penerapan adaptif fuzzy pada pengaturan kecepatan motor induksi tiga fasa", Jurnal Teknik GELAGAR Vol. 18 No. 1, Apr 2007.

[2] R. Sumanjaya, E. Susanto, dan P. D. Wibawa, "Perancangan simulasi sistem kontrol kecepatan motor induksi 3 fasa dengan metode control scalar", Jurnal EPROC, 2015.

[3] D.W. Hart, Power Electronics, Mc. Graw Hill, New York, 2011.

[4] M. Alizadeh, M. Masoumi, dan E. Ebrahim, "Closed loop speed control of induction motor using constan V/F applying SPWM and SVM based inverter", International Journal of Engineering and Advanced technology (IJEAT) Vol. 6 No. 5, Jun 2017.

[5] P. Sutawinaya, "Pengembangan model fuzzy Mamdani untuk pengaturan kecepatan motor induksi tiga fasa berbasis metode control filed oriented", Jurnal LOGIC Vol. 13 No. 2, Jul 2013.

[6] Y. Chen, B. Yang, A. Abraham, dan L. Peng, "Automatic and design of hierarchical takagi-sugeno type fuzzy systems using evolutionary algorithms", IEEE Transaction on Fuzzy Systems Vol. 15 No. 3, Jun 2007.

[7] Husnawan, Pengaturan Kecepatan Motor Induksi Menggunakan Logika Fuzzy, Tugas akhir, Departemen Teknik Elektro, Universitas Indonesia, Jan. 2008.

[8] Sukamto, "Pengendalian kecepatan motor induksi menggunakan controller logika fuzzy", Jurnal of Electrical Electronic Control and Automotive Engineering (JEECAE) Vol. 4 No. 1, Mei 2019.

[9] D. S. Aji.P, M. Sarwoko, dan E. Kurniawan, "Kontrol kecepatan motor induksi tiga fasa menggunakan tegangan dan frekuensi dengan modulasi vector ruang", Jurnal Penelitian Dan Pengembangan Telekomunikasi, Kendali, Komputer, Elektrik Dan Elektronika (TEKTRIKA) Vol. 1 No. 1, Jan 2016. 